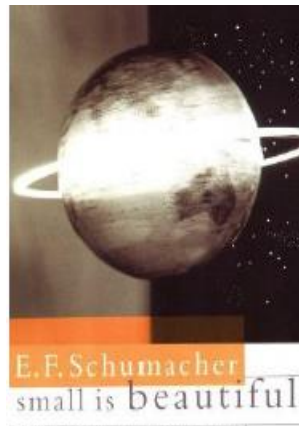

*Written by E.F. Schumacher

Small is Beautiful - A

Study of Economics as

if People Mattered

BOOK REVIEW

Sri Lanka Journal of

Economic Research

Volume 3 (2)

December 2015: 115-120

Sri Lanka Forum of

University Economists

Vintage Books, London (1993)

SLJER

272 Pages, Price: UK £6.99

SBN: 0-09-922561-1

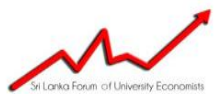

D.I.J. Samaranayake

Department of Economics and Statistics

University of Peradeniya, Sri Lanka

Telephone: 071-2919780

Email: janaranjanasamaranayake@gmail.com

\title{
INTRODUCTION
}

Completion among social disciplines and scientific methodology has been captured in all socio-economic dynamics into one particular parcel which introduce as the 'mainstream' of contemporary academia. This has been raptured all academics who deals within a comfort zone while facilitating more objective approaches. In economics also this is a popular subject matter which organizes its path coherent to more objectified method exclusive from other disciplines. It relays under number of assumptions and less generalized conclusions. Therefore, number of academics tends to question and criticize those fundamentals of mainstream economic modules. Ernst Friedrich Schumacher is one of that innovative "anti-objectify" economists and philosophers who contribute to sustain the argument: "studying economics is only one outlet of knowledge and it needs assistance of other social disciplines to be more progressive and to address the natural phenomenon". Therefore, his academic writings address more subjective approaches with the essence of spirituality and philosophy of modern thinking. 
Schumacher, a British economist was a worldwide influential economic thinker with a professional background in statistics too. Small is Beautiful is a collection of essays written and compiled by him under four major parts namely, "The Modern World", "Resources", "The Third World" and "Organization and Ownership". All these parts are split into smaller components, which are linked to each other, but are strongly influenced by different lecture notes, articles and quotations.

In advance, this book basically questions many assumptions used in mainstream economics and highlights some popular delusions. It was first published in 1973 by Blond \& Briggs Ltd, London during the time United Kingdom entered into European Economic Community. Also it became a one of the ground breaking publication during the period of energy crisis (around 1973). Then it was published again by Vintage publishers in 1993. This edition includes an attractive introduction by Jonathon Porritt as an edition to the previous edition. The edition in 1993 will be review in this paper. Moreover, it is known as one of the most influential 100 books published since World War II and is regarded as an influential by modern intellectuals. Therefore, it is worth writing a book review on this publication which argues against excessive materialism and meaningless growth with very useful subjective approach for modern thinking in economics.

\section{ORGANIZATION OF CHAPTERS}

As already mentioned, this book consists of four major parts (Chapters). The first part "The Modern World" was split into five sub-parts namely, a) The Problem of Production, b) Pease and Permanence, c) The Role of Economics, d) Buddhist Economics and e) A Question of Size. This part basically questions the myths and fallacy ideologies that occur through more objectify analysis regarding complex human choice and actions. Therefore, the part provides strong arguments against economists who often mislead true nature of environment and economy.

For an example, the author highlights that either capitalists or socialist ideology has failed to clearly recognize margins of the nature and human begins. Since mankind is aiming unlimited growth with limited resources from the environment, problem of production may occur. People fail to use adequate measures to identify true costs that can occur which we do not include in cost calculations on what nature provide. Therefore, Growth of National Product will not be the accurate and suitable way to measure human substance. Moreover, the author discusses about the belief that 'Rapid Economic Growth is a way into a brighter future'. According to 
Schumacher, people may be more peaceful and happier if they are rich and can consume more. Here he has mentioned about a universal prosperity and happiness which will become true along with three hypotheses (1) It is possible to achieve universal prosperity (2) This achievement is possible with the basis of 'enriching your selves'. (3) It is the way to peace. Then some remarkable comments through the third and fourth sub parts reveal how economics should be modified to accommodate local needs, beliefs and specialties. Finally, he questioned the common belief at the time; 'The big is better'. His argument provides very important facts to think twice about the large scale technology as the root of degrading human beings and environment.

The second part of this book "Resources" was split again into five sub-parts namely, 'The Greatest Resource - Education', 'The Proper use of Land', 'Resources for Industry', 'Nuclear Energy - Salvation or Damnation' and 'Technology with a Human Face'.

Schumacher starts this part while emphasizing the importance of education as the most vital resource of all. The key factor of all economic development comes out of human mind. However, the author lets readers to think twice about the knowledge and mind. Education is all about gaining knowledge. But the nature of knowledge may depend upon the influence of fixed ideas in our mind to the learning system. Moreover, Schumacher demonstrates how mankind split into two different roles; the consumer and producer. Then he uses the agricultural sector and proper land usage as evidence to demonstrate that how people generate negative consequences on themselves without compromising the above two roles under the basis of profit seeking behaviour? At the final phase of the second part Schumacher investigates the applicability of nuclear energy as an energy source for the future world and also to the environment. As in his projections, economic prosperity of the world seems to be linked with nuclear energy (Which is a vigorous energy source recently) but with critical environmental issues with non-destroyable radioactive waste. In addition to that, the fifth sub-part provides some arguable comments on the use of technology. According to him, technology should respond to actual needs of people and it should enable people to use their creativity along with local necessities.

The third part of this book "The Third World" was split into four sub-parts namely, 'Development', 'Social and Economic Problems Calling for the Development of Intermediate Technology', 'Two Million Villages' and 'The Problem of Unemployment in India'. This part basically uses the practices from under developed countries as a proxy to investigate the role of intermediate technology for the development of under-developed economies. Schumacher argues that the 'trickle-down theory' may not improve the level of employment of people in an equal manner. It will 
usually increase the per capita net income for people in urban areas but not the ones living in rural areas. As the author mentions the industrial mode of production is not a sustainable application for an economy since it obstructs the availability of natural resources as well as the quality of nature. Moreover, he has mentioned that the problem of production may not be solved through a changing approach from capitalist to socialist because this issue may not occur as a result of either capitalist or socialist class structure. On the other hand, he identifies the Indian unemployment issue as an evidence to strengthen his arguments and confront the Western technology. Massive rural to urban migration and the lack of infrastructure for such technology may create adverse effects on India through these Western applications. Therefore, Schumacher believes that instead of capital incentive technology, inexpensive small-scale labour incentive technology may improve economic conditions of rural India.

The fourth and final part of this book "Organization and Ownership" was split into five sub-parts a) A Machine to Foretell the Future, b) Towards a Theory of Large-Scale Organization, c) Socialism' and 'Ownership' and d) New Patterns of Ownership'. This part was written by Schumacher to distinguish the ownership dimensions, especially about public and private ownership in terms of economic development. He revisits the logic of profitability and highlighted that publicly owned capital should not estimate under the profit seeking strategies. Moreover, he suggests private ownership is best to use with small-scale enterprises. When the size of the enterprise is large it may create issues on the private ownership. Therefore, large scale organization management should adapt with proper and suitable framework to make the ownership a success.

\section{SIGNIFICANCE OF THE CONTENT}

This book is a remarkable attempt by Schumacher to address very common but vital questions occurs in different economies. It explains very complex economic matters in a simple way to understand the content of the book even though the reader should not be an economist. This simplicity as well as the depth of contemporary issues and arguments made this book an influential collection of essays at the time.

Schumacher argued about the myth of mainstream economic approaches which are more orthodox and objectify in their analytical basis. In his writings, unlike pure sciences, economics is concerned with complex human choice and actions. Therefore, economists who relied upon objective approaches may often be misled and failed to capture true behaviour of human beings. He criticizes not only the capitalist orthodoxy economists 
but also the socialist. Capitalist as well as socialist causes number of failures throughout the process of reasoning for the problem of production, extremely rare capital, use of technology and ownerships. In addition to that, his intellectual critiques compound with moral states over some facts of Keynesian economic theory which is remarkable.

Schumacher appears to be a much more radical writer compared to Keynes. For an example, Keynes identifies production as a necessary requirement because it gave us material prosperity and employment and would bring us to the point where good life could be enjoyed. But Schumacher raises his ideas to confront this belief and highlights adverse effects which can occur through industrialization to the environment as well to the human beings. His ideas and critiques persuade through experience from travels to Burma; a nation compiled with Buddhist culture with more moral and psychological applications. Moreover, his ideology of small-scale technology while criticizing a dominant concept where "larger the scale will larger the returns of production" create new trend among radical economic thinkers. Therefore, Small is Beautiful has become more influential publication which compiled with attractive arguments persuade through the strength of Schumacher's evolution of critiques.

Roots of Buddhist Economics were nourished through Schumacher's intention to promote more subjective economic analysis. Western economic beliefs and policies attempt to maximize the consumption by optimize effort and scale of production. This perspective was redefined in Buddhist Economics as maximize the satisfaction by optimize effort and scale of consumption. Moreover, in Buddhist Economics, providing labour is essential for happiness and development of each person but not to enlarge the scale of production. In addition to that there are number of applications which are comes through Buddhist philosophy to stream of economics from this book such as intermediate path for technology and new thinking pattern for human beings apart from offer values of greed and profitability.

Another remarkable feature in this book is the quality and strength of the predictions regarding various matters. Schumacher predict the future through mixing up certainties and uncertainties while demonstrating the applicability of this publication for pathfinders in future. For an example, at the second sub-part - "The Modern World"-, he predicts the size of population, fuel consumption and fuel consumption per head for the initial stages of $21^{\text {st }}$ century. Furthermore, it includes separate prediction for two dimensions, rich and poor. Predicted size of the population in the world is 6.9 billion. This figure has been overcome today in the real world. Not only have these statistical predictions, conceptual predictions also become more success, for an example use of small scale technology benefited both 
environment and mankind within recent practices. This feature was embarked by Jonathon Porritt in his introduction of this publication.

"Small is Beautiful! That deceptively simple notion still resonates very powerfully throughout the Green Movement today, reminding us all of the wonderfully inspirational life and work of one of the great figures of the modern age." - Jonathon Porritt (pp. X)

\section{CONCLUSION}

Schumacher is an economist who strongly believes in the picture of reality to read the complex human behaviour. His attempt to build a concrete argument against the conventional mainstream approaches of knowledge has pioneered by this influential collection of essays. This reminds the economists how resources, environment and human begin can be ruined through fallacy, beliefs and values in academia. Schumacher entered to his writings by investigating weaknesses of Western beliefs of economic wellbeing trough production. As he mentioned, Western beliefs push economies towards a growth paradigm. Way to generate wealth is unsustainable. Inefficiencies and social breakdowns can occur with irrational economic measures. Big is not always better and local small-scale production leads to the best social and environmental outcome.

Moreover, this book exposed the strength of moral and philosophical essence in subjective knowledge by promoting Buddhist Economics approach in economic analysis. Applicability of intermediate technology with lessons from underdeveloped countries and validity of labour to make peoples' life better and happy are also other key arguments emerge. Smallscale technology with a suitable framework of ownership to serve human beings was better than large scale technology at the service of economic growth.

It is worthy to note that reader may find greater part of issues discussed in this book is related with contemporary issues in modern world. But if he looks at the year when it first came out, reader would be surprised that this book was first published in 1973. Because those issues discussed in this book are still pretty much relevant and applicable as of today. Therefore, Small Is Beautiful can identify as one of gigantic movement in field of moral applications in economics and subjective approaches of knowledge at the second half of the $20^{\text {th }}$ century. 